\title{
Optimalization of Bioconversion Prosess of Palm Kernel Cake for Production Maggot Hermetia Illucens as A Source of Animal Protein in Fish Farming
}

\author{
Rietje J.M Bokau and Pindo Witoko \\ State Polytechnic of Lampung \\ *Coresponding author: rietjebokau@gmail.com
}

\begin{abstract}
Rietje J.M Bokau and Pindo Witoko. 2017. Optimalization of Bioconversion Prosess of Palm Kernel Cake for Production Maggot Hermetia Illucens as A Source of Animal Protein in Fish Farming. Aquacultura Indonesiana, 18 (1): 20-25. The process of bioconversion of palm kernel cake (PCK) for the production of Black Soldier Fry larva biomass as a fish feed can be improved by fermentation process. The purpose of this research was to determine the amount of biomass production and nutritional content of maggot as a result of bioconversion fermented palm kernel cake (PCK) by using probiotic. PCK used in this research were obtained from one of palm processing industry (PTP VII Lampung). Fermentation process was using microbes (probiotics) amount of 0\% (F0), 3\% (F3), 4\% (F4), and 5\% (F5) in 1 liter of water, then it's mixed with PKC to help fermentation process. Each treatment was using 3 replication. The fermentation process was done in a 3 liters volume of bucket covered by perforated black plastic/trash bag to avoid the heat by light and the rainwater. The buckets were prepared, placed and stored in a cool and humid place by using a bamboo/wooden racks. If the media was prepared, Black Soldier Fly (BSF) insect would automatically come and lay its eggs on it.. Observations were made within 2 weeks after the media were prepared and then harvested 3 times during one week. The biomass of harvested maggot were clasified into 3 group of size, they are $<1 \mathrm{~cm}, 1-1.5 \mathrm{~cm}$, and $>1.5 \mathrm{~cm}$, then the weight were measured. The result showed that the fermented media did not give any affect for the biomass of maggot, but had an effect on the maggot nutrition. The biomass of maggot in the treatment F0 (control) was not significantly different from treatment F3 (3\%) (p>0.05), while the higher dose of probiotic (F4 and F5) were lower than control. The proximate composition of maggot showed that crude protein and fat parameter were significantly different for every stage of fermentation treatment. Treatment F3 has the highest crude protein and significantly different from F0 and F5 ( $<<0.05)$, while the fat contents decreasing significantly at higher fermentation dose. Likewise, the total amino acid, in fermentation F3 was significantly higher compared to control and other treatments. Thus, the dose of fermentation (probiotic in water) $3 \%$ for the PKC was optimal to produce biomass and nutritional content of maggot.
\end{abstract}

Keywords: Bioconversion; Hermetia illucens; Palm kernel cake

\section{Introduction}

Lampung is one of the provinces in Sumatera island with significant potential in palm oil industry. From fresh fruit bunch production of 173,376 ton in 2012, $2.5 \%$ of that value was palm kernel (Central Bureau of Statistics, the Province of Lampung, 2013). It was reported that from 100 tons of palm fruit can be produced 2.1 tons of palm kernel cake (PKC) and this amount has not been optimally utilized.

Palm Kernel Cake (PKC) was used as feed raw material for livestock, poultry and fish (Swick, 1999; Sinurat, 2012; Zarkani and Miswarti, 2012), whereas in fact, the utilization of palm kernel cake for feed raw material is very low (Sinurat, 2012) when compared with its other potential. As the feed raw material, PCK has high fiber content which can reduce food digestibility and absorption, especially in fish, besides the other limiting factors. Thus, it is required to have an alternative utilization of PCK as the source of feed protein (Sukadi, 2003) which is simpler and available for the fish by transforming it from vegetable protein to animal protein through bioconversion process (Fahmi, 2015). Bioconversion is a recasting process of organic waste into methane energy source through fermentation involving living microorganisms such as bacteria, fungus, and insect larva (Newton et al., 2005). Bioconversion process produces biomass agent that are useful for fish feed such as maggot, which is the larva of Black Soldier Fly (BSF) (Hermetia illucens).

Bioconversion process of palm kernel cake in producing biomass of BSF larvae can be increased on fermentation with the addition of probiotic material (Fahmi, 2015) as pretreatment 
before BSF female flies to lay their eggs on the PKC media. This process help larva reducing waste (PKC) and expected large amount of BSF larva with better nutrition and shorter harvest time. The result of this bioconversion can be used as feed resources, either as fresh feed (fresh) or in the form of maggot flour. So from the results of this study is expected to provide information on the production of biomass and the nutritional properties of maggot are appropriate from culture naturally.

\section{Materials and Methods}

This research was carried out in the Laboratory of Fish Cultivation, State Polytechnic of Lampung. This laboratory has natural culture (outdoor) for the maggot by using the palm kernel cake (PCK) as the media which was obtained from the palm oil processing industry in Bekri, Lampung. The instruments used as the container of the fermentation media and maggot growth included 12 plastic buckets in 3 liter volume. The research was carried out in 3 months starting from June to August 2016.

\section{The Preparation of Maggot Culture Media}

Initially, the culture media material (palm kernel cake) was fermented. It was first sifted and weight in $1 \mathrm{~kg}$ for each container. The fermentation used the decomposing microbe (probiotic) of $0 \%(\mathrm{~F} 0), 3 \%(\mathrm{~F} 3), 4 \%(\mathrm{~F} 4)$, and $5 \%$ (F5) in 1 liter of water to help the fermentation process with 3 repetitions for each treatment. Probiotics used were certain probiotics for plants with bacterial fermentation content of the genus Lactobacillus fermented mushrooms, Actinomycetes photosythetic bacteria, bacterial solvent phosphate and yeast. This probiotic is the commercial one and available in market.

The addition of water (mixed with probiotic) was carried out slowly on the media by 1.5 liter each and then evenly stirred and loosen. Then, the containers were covered with holed black plastic/trash bags to avoid light and rainwater. The buckets were stored and placed in cool, humid and vegetated place by using wooden/bamboo racks. The stirring was done 2-3 times within the fermentation process (7 days) to have evenly moisture media. To ensure the existence of larva, the observation was begun after the media was prepared. In this process, Black Soldier Fly (BSF) insect would automatically come and lay its eggs on it.

\section{The Observation of Bioconversion Process}

This phase included the observation on the larva growth, starting from the egg, larva, prepupa, pupa and adult insect based on its morphological descriptions. Biomass was calculated based on the result on each harvest until the condition of the media became unproductive. The composition of harvesting size of the larva maggot was determined by calculating the number of larva grouped by the size (Fahmi, 2015).

\section{Maggot Harvesting and Proximate Test}

The developed and grown maggots were harvested every week at the day 21,28, 35 and so on. Young maggots with small size were harvested as fresh feed. Large size maggots were harvested and separated to make flour. In the maintained period, daily observations were made on the condition of culture media to ensure the growth of maggots. Harvest was carried out by separating maggot from the growing media, which was by loosening it under the sunlight or when the maggot moved upward. When the maggots were on the media surface, they were collected and put into separated container (Silmina et al., 2011). Harvested maggots were divided based on the sizes (small, medium, and large) and weighed. The maggot size varied because eggs were not stocked. Instead, it was naturally laid. The nutrient content (proximate composition) of the maggot was tested by AOAC method (AOAC, 1999) in the Agricultural Technology Laboratory, Politeknik Negeri Lampung. The amino acid composition was determined by HPLC method and carried out in Integrated Chemistry Laboratory, Bogor Agricultural University.

\section{Parameters}

The parameters observed in this study were maggot production (gram), calculated from the total weigth of the maggot harvested after the bioconversion process. Nutritional of maggot through proximate test (water level, protein, fat, fiber, and ash), amino acid content by comparing the treatment and non-fermentation probiotik.

\section{Design Experiment and Statistical Analysis}

Addition rates at $\mathrm{PKC}$ media as treatment in this research are $0 \%(\mathrm{~F} 0), 3 \%(\mathrm{~F} 3), 4 \%(\mathrm{~F} 4)$, and $5 \%$ (F5) in 1 liter of water, each treatment 
are repeated 3 times. Until produces 12 test medium and are arranged randomly, then are put outside the room. Maggot production and proximate composition of maggot flour were statistically analyzed using one-way analysis of variance (ANOVA) and multiple comparisons among treatment means were made with Duncan's multiple comparison test using the Statistical Analysis Software Program of SPSS version 21 for Windows. All probability values were considered statistically significant at the level of $\mathrm{P}<0.05$. The amino acid profile of maggot flour by comparing the results of nonfermented medium (F0) and F3 (3\%), F4 (4\%) fermentation, in descriptive analysis.

\section{Result and Discussion}

\section{Maggot Production}

Naturally female insects Hermetia illucens lay their eggs around the substrat (palm kermel cake). The success of this process are strongly influenced by the nature of media and environmental conditions of breeding. In this activity it takes several appropriate test locations such as vegetated and humid areas so the female parent puts eggs on prepared media and hatch after 3-6 days (Myers et al 2008; Tomberlin et al. 2002). Hatched eggs then develop into larvae better known as Maggot which is the longest phase of its life cycle which ranges from 2-3 weeks until its develop into adulthood. For 2 months activity can be done 3 times maggot harvesting with different size that is: small size $(<1.0 \mathrm{~cm})$, medium size $(1-1.5 \mathrm{~cm})$, and large size $(>1.5 \mathrm{~cm})$. The harvest $(\mathrm{g})$ showed that the larger size was higher in biomass then the small and medium size (Figure 1).

Biomass maggot $(\mathrm{g})$ produced from $1 \mathrm{~kg}$ of palm kernel media vary. The highest production was $178.12 \mathrm{~g}$ obtained from media F0 (no fermentation). Others were $172.61 \mathrm{~g}, 79.09 \mathrm{~g}$, and $14.06 \mathrm{~g}$ obtained from fermented media (F3, F4, and F5), respectively. Such result indicated that biomass of maggot is not affect of fermentation in PKC media, where the treatment of F0 is not significantly different from the treatment of F3 (3\%). At higher doses (F4 and F5) maggot production is lower and significantly different with F0 and F3 (Table 1). Observation during bioconversion process shows that $\mathrm{PKC}$ medium reduces about $30-50 \%$ and its color change from brown to blackish at the end of the process. Besides, media temperature rising occurred due to fermentation process which is on day 3 and 4 reach $40-45^{\circ} \mathrm{C}$ then declined to normal temperature and on day 7 maggot can be harvested. Chemical nature of PKC media also change at PKC media fermentation (F3, F4, and F5) $\mathrm{N}$ amount (protein total) to $18.20 \%$, fat $12.33 \%$ and fiber amount $28.93 \%$. Bintang et al. (2003) mention that amount of protein, fat, and fiber of PKC were $15.3 \%, 8.9 \%, 15 \%$ each. Probiotic usage have a role at fermentation process of media in early process (about 3 days) until the time BSF parents lay its eggs on media and they hatched, bioconversion process will continue by larvae with its life process. Either on probiotic treatment media or non probiotic media treatment can be used by larvae.

The numbers of maggot harvested effectively within 2 months varied, influenced by the media condition. The fermentation treatment by using various probiotic dosages on the palm kernel cake media showed that higher dosage of probiotic would result in less number of maggots. Rana et al. (2015) explained that the variation of larva production was influenced by the odor of the media to stimulate the BSF female flies to lay their eggs, as well as by the media nutrition characteristic. As bioconversion agent, larvae phase (maggot) needs food (nutrition) and will continually eat until metamorphosis phase becoming prepupa (Mangunwardoyo et al., 2011; Fahmi, 2015). Although the addition of probiotic could improve the PCK media nutrition and condition, in larger dosage, it might reduce the odor characteristic. Therefore, at 5\% probiotic dosage, the result was the lowest. Maggot Hermetia illucens can be developed on the media with organic substance (Tomberlin et al., 2002, Fahmi, 2015) such as PCK in this research. According to Oliver (2004), maggot larvae is adaptable to the condition of nutrient media in inadequate nutrient condition, larval growth will be 4 months, but when the nutrient is in adequate condition, it only requires 2 weeks for growth. By adding probiotic in this study, the larva phase on various media can be less than 2 weeks.

\section{Proximate Composition of Maggot Fluor}

Harvested maggots on each media treatment were dried under the sun in 3 days to be then grinded for proximate analysis. The result of the analysis shows that at proximate parameter (\% wet matter), water level (5.7-6.1\%), carbohydrates $(1.75-1.9 \%)$, crude fiber (9.2$9.4 \%)$ and ash $(10.6-10.7 \%)$, for all treatment 
stages of the parameters were not significantly different either F0, F3, F4 and F5 (p>0.05). While crude protein parameters $(45.8-56.5 \%)$ and fat (20.9-25.9\%) were significantly different among treatment $(\mathrm{p}<0.05)$ (Table 1). Based on \% wet matter, there were significantly different crude protein between unfermented (F0) as control and fermented (F3, F4, and F5) treatment media, while the fermentation treatment was not significantly different). As the bioconversion agent, maggot was able to utilize the PKC organic waste media (fermented) to grow and establish its protein. Media with good quality would give positive influence to the protein content of Hermetia illucens maggot. Likewise for fat content, showed that F0 (control) was significantly different from treatment (F3, F4, and F5), while among the treatments showed that increasing dose of probiotic for media fermentation had an effect on decreasing fat level of maggot. Some previous researches using PCK media resulted in lower protein content $(42,1 \%$ $44.01 \%$ ) of maggot (Oliver, 2004; Newton et al., 2005, and Rachmawati, 2010). According to Mangunwardoyo et al. (2011), during the media bioconversion process, protein content increases. Nitrogen is the main component of a cell protein in which the nitrogen consumption has direct effect on the protein synthesis in the organism or microbe cell (Swick, 1999). Protein is a very important nutrient in the composition of artificial feed formulation for fish. Protein produced from the bioconversion is useful to provide nutrition needed by the fish. Treatment with $3 \%$ probiotic (F3) which result $56.5 \%$ crude protein is assumed as the optimum proses. Although $4 \%$ (F4) and
5\% (F5) showed high protein content $(54.9 \%$ and $53.17 \%$ ) but have low fresh maggot production. The fiber was also important in fish feed which was indicated by lower fiber content than other research results reported by Jaelani et al. (2010) it was $17.88-28.36 \%$ and Mangunwardoyo et al. (2011) it was 28.93-3.32\%). Although in small quantity, fiber is important to assist in the digestion process of food in fish.

\section{The Amino Acid Profile of Maggot Flour}

Composition of the amino acid of maggot flour obtain (F0, F3, and F4) was compare to the amino acid of fish flour (Table 2). The protein quality was correlated to the essential amino acid. Imbalanced amino acid would cause low availability of one or more essential amino acids in the feed, together with the low protein retention and high ammonia excretion (Handayani and Widodo, 2010). There was a difference of total amino acid between maggot flour from non-fermentation medium F0 (28.37\%) and fermentation medium F3 and F4 (36.49\% and 33.08\%), which showed that the fermentation treatment using 3\% probiotics was better. Similar to all nine essential amino acid (EAA) were detected and in all treatment excluding tryptophan which was not analyzed in the current study. Some EAAs whose content is relatively higher in the treatment of F3 are valine $(2.91 \%)$, iso-leucine $(2.91 \%)$, leucine $(3.10 \%)$, and lysine $(2.55 \%)$. Nevertheless, the EAA content resulting from this study is still lower than fish flour (menhaden) (NRC, 1994) and maggot flour (Newton, 1977) with different media

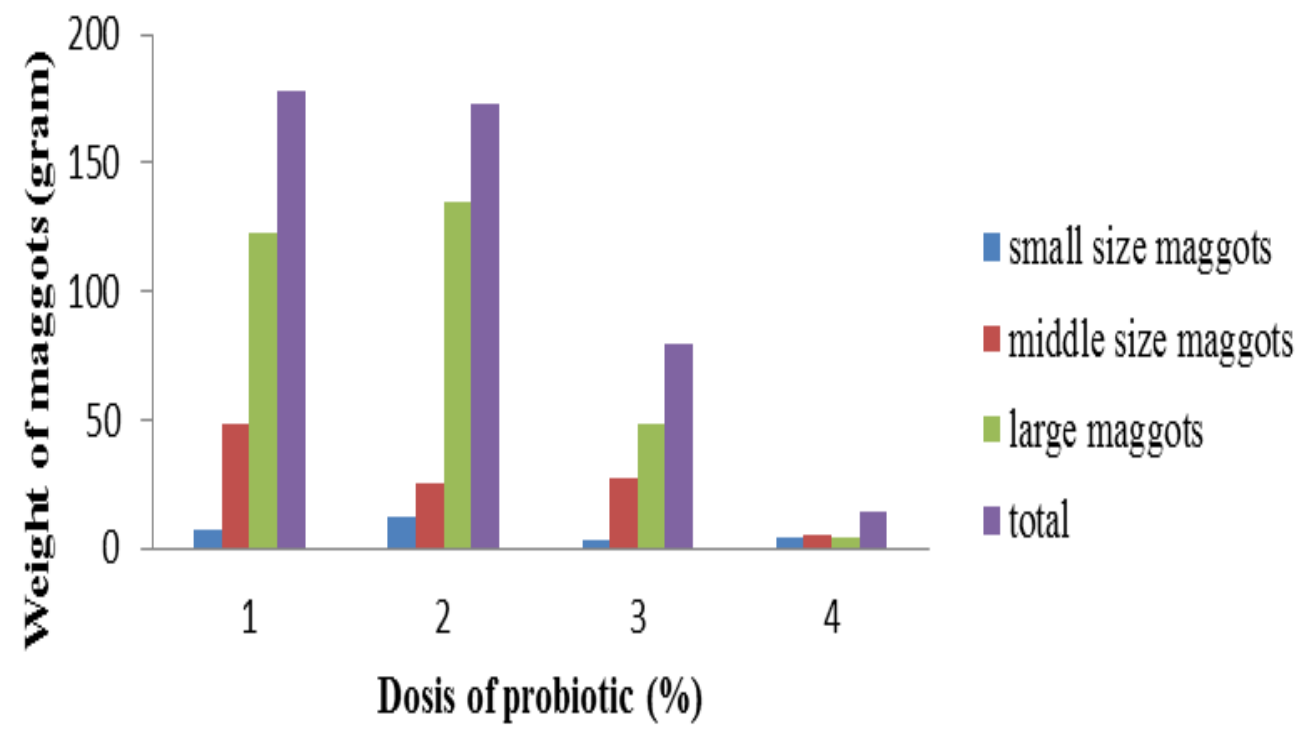

Figure 1. Production of Maggot (gram) in various sizes in media treatment 
Table 1. Total maggot (gram) and proximate composition (\% wet basis) of flour maggot from each fermentation media.

\begin{tabular}{lcccc}
\hline & \multicolumn{2}{c}{ Dose of probiotic $(\%)$} \\
Parameter & F0 $(0 \%)$ & F3 $(3 \%)$ & F4 $(4 \%)$ & F5 $(5 \%)$ \\
\hline Total maggot (gr) & $178.12 \pm 13.4^{\mathrm{a}}$ & $172.61 \pm 36.4^{\mathrm{a}}$ & $79.1 \pm 2.5^{\mathrm{b}}$ & $14.1 \pm 6.1 \mathrm{~b}^{\mathrm{c}}$ \\
Water (\%) & $5.7 \pm 0.1^{\mathrm{a}}$ & $5.9 \pm 0.9^{\mathrm{a}}$ & $6.1 \pm 0.6^{\mathrm{a}}$ & $7.05 \pm 0.3^{\mathrm{a}}$ \\
Crude protein (\%) & $45.8 \pm 1.7^{\mathrm{a}}$ & $56.5 \pm 2.6^{\mathrm{b}}$ & $54,9 \pm 1.9^{\mathrm{b}}$ & $53.17 \pm 1.4^{\mathrm{bc}}$ \\
Carbohydrate (\%) & $1.9 \pm 0.3^{\mathrm{a}}$ & $1.9 \pm 0.1^{\mathrm{a}}$ & $1.9 \pm 0.1^{\mathrm{a}}$ & $1.75 \pm 2.1^{\mathrm{a}}$ \\
Fat $(\%)$ & $25.9 \pm 0.4^{\mathrm{a}}$ & $23.0 \pm 0.9^{\mathrm{b}}$ & $20.9 \pm 0.3^{\mathrm{c}}$ & $18.94 \pm 1.1^{\mathrm{c}}$ \\
Crude fiber (\%) & $9.3 \pm 0.2^{\mathrm{a}}$ & $9.4 \pm 0.2^{\mathrm{a}}$ & $9.2 \pm 0.1^{\mathrm{a}}$ & $9.6 \pm 0.1^{\mathrm{a}}$ \\
Ash $(\%)$ & $10.7 \pm 0.1^{\mathrm{a}}$ & $10.5 \pm 0.2^{\mathrm{a}}$ & $10.6 \pm 0.2^{\mathrm{a}}$ & $10.48 \pm 0.3^{\mathrm{a}}$ \\
\hline
\end{tabular}

Values are means \pm SD of three replicates. Means values having the same superscript are not significantly different $(\mathrm{p}>0.05)$

Table 2. Amino Acid Profile (\% w/w) of Maggot Fluor from Fermented and Non-fermented PKC Media

\begin{tabular}{lccc}
\hline \multicolumn{1}{c}{ Kind of AA } & Non-Fermented Media $(\mathrm{F} 0)$ & Fermented Media (F3) & Fermented Media (F4) \\
\hline Aspartic acid & 2.63 & 3.47 & 3.03 \\
Glutamic acid & 3.54 & 5.23 & 5.00 \\
Serine & 1.28 & 1.64 & 1.53 \\
Glysine & 1.94 & 2.26 & 2.08 \\
Histidine & 0.93 & 0.95 & 0.83 \\
Arginine & 1.82 & 2.24 & 2.16 \\
Alanine & 3.17 & 4.04 & 3.63 \\
Threonine & 1.39 & 1.55 & 1.40 \\
Tyrosine & 1.64 & 2.19 & 1.94 \\
Valine & 2.32 & 2.91 & 2.63 \\
Methionine & 0.29 & 0.45 & 0.43 \\
Isoleucine & 1.51 & 2.13 & 1.93 \\
Leucine & 2.58 & 3.10 & 2.83 \\
Phenylalanine & 1.15 & 1.77 & 1.54 \\
Lysine & 2.18 & 2.55 & 2.12 \\
\hline Amino Acid Total & 28.37 & 36.49 & 33.08 \\
\hline
\end{tabular}

\section{Conclussion}

Maggots nutrition from non fermented and fermented media in this study is feasible as a raw materials for fish feed. Based on the results of total production of maggot, proximate test and amino acid profile, PKC fermented media at level $3 \%$ was optimal for maggot production. In fermented media PKC, nutrition of maggots such as crude protein and total amino acid was improve.

\section{Acknowledgments}

The authors gratefully acknowledge to Ministry of Research, Technology and Higher Education for funding support by Grant Competition 2016. We also sincerely thank to assistants of Aquaculture Laboratory, State Polytechnic of Lampung.

\section{Reference}

Assosiation of Official Analytical Chemists (AOAC). 1999. Official Methods of Analysis, $16^{\text {th }}$ edn.
Assosiation of Official Analytical Chemists International, Gaithersberg, Maryland, USA. $1141 \mathrm{pp}$.

Bintang, I., A.P. Sinurat dan T. Purwadaria. 2003. Respon broiler terhadap pemberian ransum yang mengandung lumpur sawit fermentasi pada berbagai penyimpanan. Jurnal Ilmu Ternak dan Veteriner, 8(2): 71-75.

Fahmi, M.R. 2015. Optimalisasi proses bioconversion dengan menggunakan mini-larva Hermetia illucens untuk memenuhi kebutuhan pakan ikan. Prosiding Seminar Nasional Masy.Biodiv. Indonesia, 1(1): 139-144.

Food and Agriculture Organisation FAO. 2002. Utilization of palm kernel cake (PKC) as feed I Malaysia. Asian Livestock, 26 (4): 19-23.

Handayani, H. and W.Widodo. 2010. Fish Nutrition. UMM press Malang.

Jaelani, A. Gunawan, and N. Widaningsih. 2010 Bioconversion of manure by maggot of black soldier and green fly. Journal Media Sains, 2(1).

Mangunwardoyo, W., Aulian and S. Hem. 2011. Utilization conversion palm kernel meal as substrate growth of Hermetia illucens L. larvae (maggot). Journal Biota, 16 (2): 166-172. 
National Research Counsil (NRC). 1994. Nutrient Requiremant of Poultry. Nineth Revised Edition. National Academy Press, Washington DC, USA, 155pp.

Newton, L.C., D.C. Sheppard, D.W. Watson, G.J Burtle, C.R Dove, J.K. Tomberlin, and E.E.Thelen. 2005. The Black Soldier Fly, Hermetia illucens, as a Manure Manajement/Resource Recovery Tool. State in Science, Animal Menure and Waste Management.

Myers, H.M, Jeffery KT, Barry DL and David K. 2008. Development of black soldier fly (Diptera: Stratiomyidae) larvae fed dairy manure. Physiologycal Ecology, 37 (1): 1115.

Oliver, P. 2004. Larval Bio-convertion.Electronic Forum on Area-Wide Integration of Specialized Crop and Livestock Production. Livestock Environment and Development(LEAD)Initiative. http://lead.virtualcentre.org/en/ele/awi_2004/ particip/oliver. ( October, 8 2010)

Rachmawati. 2010. Life history of Hermetia illucens (Linnaeus) (Diptera: Stratomyidae) in palm kernel cake. Tesis. Magister Program of Bogor Agriculture Institute.

Rana, K.M.S., M.A. Salam, S. Hashem, and Md. A. Islam. 2015. Development of black soldier fly larvae production technique as an alternate fish feed. International Journal of
Research in Fisheries and Aquaculture, $5(1): 41-47$.

Sinurat, A.P. 2012. Technologi of byproduct from palm industry to improve the available of national poultry feed material. Inovasion Agriculture Development 5(2):65-78.

Silmina, D., G. Edriani, M. Putri. 2011. Efectivity berbagai media budidaya terhadap pertumbuhan maggot Hermetia illucens. IPB Bogor.

Sukadi, M.F. 2003. Strategi and Kebijakan Pengembangan Pakan Dalam Budidaya Perikanan. Prosiding Semi-Loka Aplikasi Teknologi Pakan and Peranannya Bagi Perkembangan Usaha Perikanan Budidaya, Bogor 9 Sept. 2003. Pusat Riset Perikanan Budidaya, DKP

Swick, R.A. 1999. Consideration in Using Protein Meals for Poultry and Swine. Asa Technical Bull., 21:1-11.

Tomberlin, JK., Sheppard D.C., and Joyce J.A. 2002. Selected life history traits of black soldier fly rear on three artificial diets. $J$. Ento Sci., 37: (4): 345-352.

Zarkani, A. and Miswarti. 2012. Teknik budidaya larva Hermetia illucens, L (Diptera: Stratomyidae) sebagai sumber protein pakan ternak melalui biokonversi limbah loading ramp dari pabrik CPO. Indonesian Journal of Entomology, 9(2): 49-56. 